\title{
Clinical and Subclinical ACTH-Independent Macronodular Adrenal Hyperplasia and Aberrant Hormone Receptors
}

\author{
Stavroula Christopoulos Isabelle Bourdeau André Lacroix \\ Division of Endocrinology, Department of Medicine, Centre Hospitalier de I'Université de Montréal, \\ Montréal, Canada
}

\section{Key Words \\ Adrenocortical hyperplasia - ACTH-independent macronodular adrenal hyperplasia $\cdot$ Cushing's \\ syndrome, subclinical $\cdot$ Aberrant receptors}

\begin{abstract}
ACTH-independent macronodular adrenal hyperplasia (AIMAH) is a very rare cause of endogenous Cushing's syndrome (CS). In this review, the clinical characteristics, the pathophysiology, and the management of AIMAH are described. AIMAH typically presents with overt CS, but subclinical oversecretion of cortisol has been increasingly described. The diagnosis is suspected by adrenal nodular enlargement on conventional imaging following the demonstration of $\mathrm{ACTH}$-independent hypercortisolism. Final diagnosis is established by histological examination of the adrenal tissue. Bilateral adrenalectomy is the treatment of choice but unilateral adrenalectomy has been proposed in selected cases. In patients with subclinical CS, the decision to treat should be individualized. The pathophysiology of this condition has begun to be elucidated in recent years. Diverse aberrant membrane-bound receptors expressed in a nonmutated form in the adrenal gland have been found to be implicated in the regulation of steroidogenesis in
\end{abstract}

This work was supported by a grant from the Canadian Institutes of Health Research (MA-10339). (c) 2005 S. Karger AG, Base 0301-0163/05/0643-0119\$22.00/0

Fax +4161306 1234 E-Mail karger@karger.ch www.karger.com www.karger.com/hre
AIMAH. When systematically screened, most patients with AIMAH and CS or subclinical CS exhibit an in vivo aberrant cortisol response to one or various ligands suggesting the presence of aberrant adrenal receptors. A protocol designed to screen patients for the presence of these aberrant receptors should be undertaken in all patients with AIMAH. The identification of these receptors provides the potential for novel pharmacological therapies by suppressing the endogenous ligands or blocking the receptor with specific antagonists.

Copyright (C) 2005 S. Karger AG, Basel

\section{Introduction}

Endogenous Cushing's syndrome (CS) is due to primary adrenal hypersecretion in approximately 15-20\% of cases [1]. Unilateral adrenal pathology, in the form of adrenocortical adenomas or carcinomas, represents the large majority of adrenal CS. Bilateral adrenal pathology causing CS represents only $10-15 \%$ of all cases and includes: (1) primary pigmented nodular adrenocortical disease (PPNAD) commonly associated with Carney complex; (2) ACTH-independent macronodular adrenal hyperplasia (AIMAH) [1], and rarely (3) bilateral adenomas or carcinomas. AIMAH is thus a very rare cause of CS representing less than $1 \%$ of its endogenous etiologies. In 1994, Lieberman et al. [2] reviewed 24 published cases. Since then, a much greater number of cases have been reported and the characteristics of this distinct entity 
have increasingly been delineated. A variety of terms have been used in the literature to label this condition including: 'massive macronodular adrenocortical disease'; 'autonomous macronodular adrenal hyperplasia'; 'ACTH-independent massive bilateral adrenal disease'; 'giant or huge macronodular adrenal hyperplasia', and 'macronodular adrenal dysplasia' [3, 4].

In this review, we will present the clinical characteristics of AIMAH, the recent data on the pathophysiology of this condition, most notably the role of aberrant adrenal receptors, and finally its treatment.

\section{Clinical Features}

AIMAH was first described in 1964 by Kirshner et al. [5] who reported the case of a 40-year-old woman with long-standing CS. They demonstrated that her hypercortisolism was ACTH-independent and that the resected adrenal glands contained multiple nodules with a combined weight of $94 \mathrm{~g}$. Since then, a number of cases have been described in the literature and the clinical characteristics of this legitimate cause of CS have been more precisely characterized.

\section{Epidemiology}

AIMAH appears to have a bimodal age distribution, with a subset of patients presenting in the first year of life [6], usually associated the McCune-Albright syndrome. Most patients present in the 5th and 6th decades [2-4, 7], representing a much later age at onset compared with unilateral cortisol-producing adenomas or pituitary corticotroph adenomas. Furthermore, this later age at onset differs from that of PPNAD, which is around 18 years of age [8]. In contrast to the predominant female distribution in most causes of endogenous CS, AIMAH appears to be equally distributed between genders $[2,3,7]$. One report suggested an increased frequency in males [9] and another an increased occurrence of gastric inhibitory polypeptide (GIP)-dependent AIMAH in women [10]. In the majority of cases, AIMAH appears to be sporadic. However, there have been reports of familial clustering with the suggestion of an autosomal dominant pattern of transmission [2, 11-15].

\section{Clinical Presentation}

AIMAH cases are discovered either because of an incidental radiological finding or following the investigation of an adrenal hypersecretion syndrome. The most common clinical presentation is CS. At the time of diag- nosis, subtle signs and symptoms consistent with CS have typically been present for a number of years. In one series, the diagnosis was delayed by a mean of 7.8 years [4]. As in any cause of adrenal cortisol hypersecretion, plasma ACTH is suppressed and the high-dose dexamethasone suppression test fails to suppress cortisol production. In recent years, the occurrence of subclinical CS defined as the absence of clinical signs of CS, slightly elevated midnight plasma or salivary cortisol, subnormal suppression following the 1-mg overnight dexamethasone suppression test $(>50 \mathrm{nmol} / \mathrm{l})$, a partially suppressed $\mathrm{ACTH}$, and a normal 24-hour urinary cortisol has been shown to occur with AIMAH. Bourdeau et al. [16] described 4 patients referred for incidentally encountered bilateral adrenal macronodular glands in whom the presence of subclinical CS was demonstrated. The natural history of AIMAH causing subclinical CS is largely unknown. Bourdeau et al. [16] reported a stable clinical course and maintenance of normal urinary free cortisol levels in 2 of the 4 patients described in whom 12-month follow-up was available. Ohashi et al. [17] reported a 7-year follow-up during which a patient with subclinical CS developed elevated 24-hour urinary free cortisol, a significant increase in the total volume of the adrenal glands, and overt CS.

Concurrent secretion of cortisol and mineralocorticoids [18-20] or of cortisol and estrone [21] have been described in patients with AIMAH. Goodarzi et al. [22] reported the case of a 59-year-old woman with pure androgen overproduction associated with macronodular adrenal hyperplasia.

\section{Radiologic Features}

The diagnosis of AIMAH and CS is suspected by typical imaging studies following the biochemical demonstration of ACTH-independent CS. Doppman et al. [23] reviewed the imaging features in 12 patients with surgically proven AIMAH. On CT scan, bilateral adrenal masses measuring up to $5 \mathrm{~cm}$ of soft tissue density usually distort and completely obscure the normal adrenal glands (fig. 1a). In some cases, the adrenal glands appear diffusely enlarged but lack distinct nodules. On MRI, T1weighted images are hypo-intense relative to the liver and iso-intense relative to muscle. T2-weighted images tend to be hyper-intense relative to the liver [23, 24]. In contrast, the nodules of pituitary-dependent macronodular hyperplasia due to chronic ACTH stimulation appear isointense relative to the liver on T2-weighted MR images [23]. The asymmetric appearance of adrenal macronodules in AIMAH has been described [2, 3, 25] and may lead to the erroneous diagnosis of unilateral patholo- 

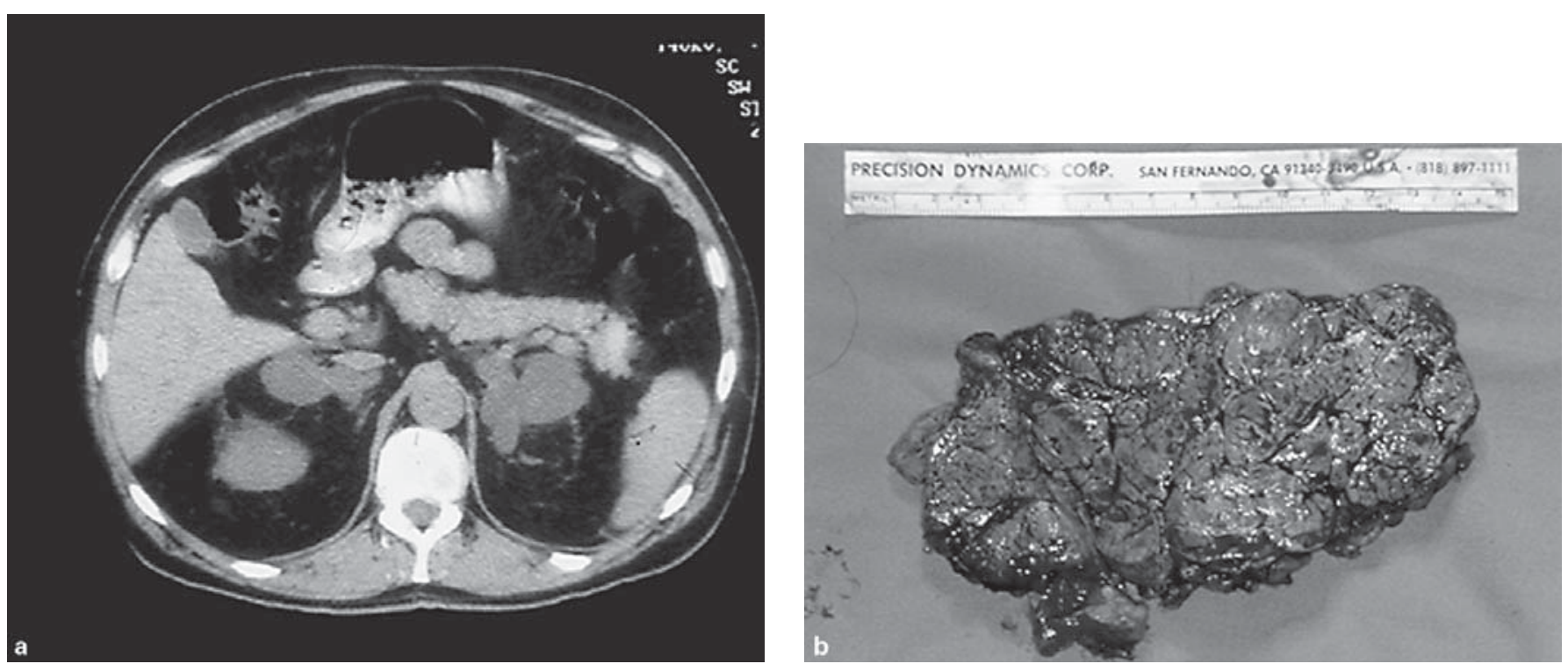

Fig. 1. a CT scan of a patient with AIMAH demonstrating bilateral adrenal nodular enlargement. b Gross macroscopy of a macronodular adrenal gland from a patient with AIMAH.

gy. Iodine-131-63-iodomethyl-19-norcholesterol (NP-59) scintigraphy typically shows bilateral uptake [26].

\section{Pathologic Features}

The combined adrenal weight is usually greater than $60 \mathrm{~g}$ and can reach more than $200 \mathrm{~g} / \mathrm{gland}$. The mean combined weight in one series was $132 \mathrm{~g}$ [23]. In comparison, the combined adrenal weight in patients with ACTH-dependent Cushing's disease has been reported to be $22.9 \mathrm{~g}$ on average in a series of 30 patients [27]. On cut sections, the nodules are yellow due to their high lipid content (fig. 1b) [9]. Final diagnosis is established by histological examination of the adrenal tissue. The nodules are composed of two cell types: Those with a clear cytoplasm (lipid-rich) that form cordon nest-like structures, and those with a compact cytoplasm (lipidpoor) that form nests or island-like structures [9, 28]. A characteristic finding is inter-nodular hyperplasia, although atrophy has been described in several cases [2, $4,8,9,29,30]$. AIMAH is a benign process that has never been shown to acquire a malignant potential or to metastasize.

\section{Differential Diagnosis}

AIMAH is distinguished from the other type of bilateral nodular adrenal hyperplasia PPNAD by: (1) a later age at onset; (2) the presence of massive macronodular adrenal hyperplasia as assessed radiologically compared with normal or slightly enlarged micronodular glands seen with PPNAD; (3) the absence of deeply pigmented nodules that appear black or brown on cut section, and (4) the inter-nodular cortical hypertrophy that contrasts with the prominent atrophy observed between nodules in PPNAD.

\section{Pathophysiology}

\section{Steroidogenesis in AIMAH}

Steroid hormone synthesis has been shown to be an inefficient process in AIMAH. Thus, the cortisol hypersecretion is the result of a significantly increased number of adrenocortical cells rather than a more efficient steroidogenesis. This compromised hormone synthesis is the consequence of altered steroidogenic enzymatic pathways. Immunohistochemical studies have revealed a differential expression of 3 $\beta$-HSD2 and CYP-17 in AIMAH that is not observed in other forms of adrenocortical pathologies: The former enzyme is exclusively expressed in large clear cells, whereas the latter is mainly expressed in small compact cells [31-33]. Immunoreactivity studies demonstrate the expression of other steroidogenic enzymes such as CYP11A1, CYP21A2, CYP11B2 to be present in both cell types, but at a decreased level, further 
contributing to the inefficiency of steroid synthesis [28, 32, 34, 35]. Furthermore, elevated 17-hydroxyprogesterone levels have been shown to occur following stimulation with ACTH providing in vivo evidence of altered adrenocortical enzymatic activity [36]. This inefficient steroidogenesis may explain the discrepancy between the sometimes subtle changes in cortisol hypersecretion such as seen in subclinical CS and the massive adrenal enlargement.

\section{Molecular Mechanisms of AIMAH}

\section{'Autonomy' Theory}

In recent years, the pathogenic mechanisms that lead to adrenal tumorigenesis and hypercortisolism have begun to be elucidated. An early theory for the pathogenesis of AIMAH hypothesized that chronic stimulation of the adrenal cortex by ACTH in long-standing Cushing's disease or ectopic ACTH secretion would lead to a hyperplastic adrenal cortex that progressively acquired adrenal autonomy [27, 37, 38]. Smals et al. [27] compared the adrenal glands of patients with AIMAH to those in patients with long-standing Cushing's disease and concluded that prolonged adrenal stimulation by ACTH resulted in adrenal bilateral nodular formation and varying degrees of adrenal autonomy. A few cases have been described in which autonomy of the adrenal gland was the result of chronic ACTH stimulation and eventually resulted in ACTH suppression [39-42]. However, the rarity of Nelson's syndrome following bilateral adrenalectomy in patients with AIMAH strongly argues against the hypothesized transition from ACTH-dependency to adrenal autonomy. In a series of 9 patients with AIMAH followed for 8.5 years after undergoing bilateral adrenalectomy, none of the patients developed Nelson's syndrome [4]. Further evidence for a primary adrenal alteration was provided by Cheitlin et al. [43] who used in vitro cell cultures from a patient with AIMAH and demonstrated a high rate of growth and maintained cortisol production despite the absence of ACTH in the culture medium.

\section{MC2R Mutations}

The possibility of a mutated ACTH receptor $(M C 2 R)$ leading to constitutive receptor activation has been examined. $M C 2 R$ mutations have not been found to be a common cause of adrenal hyperplasia or tumor formation [44-46]. Swords et al. [47] reported a patient with AIMAH in whom a $M C 2 R$ mutation $(\mathrm{F} 278 \mathrm{C})$ in the Cterminal of the receptor led to impaired desensitization and internalization of the receptor and consequently elevated basal cAMP. The same authors recently described a patient with clinical hypersensitivity to ACTH resulting from two mutations in the same allele of $M C 2 R$. The presence of either mutation alone ( $\mathrm{C} 21 \mathrm{R}$ or $\mathrm{S} 247 \mathrm{G})$ produced an inactive receptor but the presence of both mutations resulted in constitutive receptor activity [48].

\section{Gsp Mutations}

Alterations in the signaling pathways downstream of the ACTH receptor have also been implicated in the pathogenesis of adrenal hyperplasia and cortisol hypersecretion. In the McCune-Albright syndrome (MAS), activating mutations of the Gs $\alpha$ subunit can occur in a mosaic pattern in the adrenal gland during early embryogenesis resulting in the constitutive activation of the cAMP pathway. The association of MAS with bilateral nodular adrenal hyperplasia and CS has been described in a number of reports in the literature [6, 49-54]. Fragoso et al. [46] identified two different $g s p$ mutations at codon $\mathrm{Arg}^{201}$ in 3 of 5 patients with CS due to histologically confirmed AIMAH and who exhibited no signs of MAS. These cases may represent variants of MAS or may be the result of late somatic mutations. However, another report failed to identify any $g s p$ mutation using direct sequencing in 13 cases of AIMAH [55].

Association with MEN1 and Familial Adenomatous

Polyposis

Bilateral adrenal nodules have also been associated with MEN1, which is caused by a mutation of the tumor suppressor gene MENIN. Bilateral adrenal enlargement was found in $21 \%$ of a series of 33 MEN1 patients [56]. In a large kindred of MEN1, the prevalence of bilateral macronodular adrenal hyperplasia was $6 \%$. To our knowledge, a sporadic somatic mutation of the MENIN gene in adrenocortical tissue in AIMAH has never been described. Bilateral adrenal nodules have also been reported in patients with familial adenomatous polyposis, but a somatic point mutation of the $A P C$ gene in the hyperplastic adrenal tissue has never been described $[57,58]$.

\section{Gene Microarray Analysis}

In a gene expression profile study of tissues from 8 AIMAH patients using large-scale cDNA microarray analysis, 82 genes were found to be upregulated, mainly genes involved in transcription, the cell cycle and adhesion; 31 genes, including those responsible for adrenal steroidogenesis, were downregulated [35]. Further work to elucidate the mechanisms by which these genes are upor downregulated will shed some light on the molecular pathways involved in adrenal tumorigenesis. 
Table 1. Aberrant adrenal receptors in AIMAH

\begin{tabular}{|c|c|c|}
\hline Aberrant receptor & In vivo screening protocol & Medical treatment options 1 \\
\hline GIP receptor & Mixed meal & Octreotide \\
\hline $\begin{array}{l}\text { Vasopressin receptor } \\
(\mathrm{V} 1, \mathrm{~V} 2, \mathrm{~V} 3)\end{array}$ & $\begin{array}{l}\text { Upright posture } \\
\text { Administration of } \\
\text { arginine-vasopressin }\end{array}$ & V1a receptor antagonist \\
\hline$\beta$-Adrenergic receptor & Upright posture & $\beta$-Adrenergic antagonists \\
\hline $\mathrm{LH} / \mathrm{hCG}$ receptor & GnRH administration & Long-acting GnRH agonist \\
\hline 5-HT4 receptor & $\begin{array}{l}\text { Administration of 5-HT4 } \\
\text { receptor agonists (cisapride } \\
\text { or metoclopramide) }\end{array}$ & 5-HT4 receptor antagonist \\
\hline Angiotensin receptor & Upright posture & AT-1 receptor antagonist \\
\hline
\end{tabular}

Aberrant Hormone Adrenal Receptors in Adrenal CS (table 1)

The mechanism by which cortisol production is stimulated in AIMAH in the face of suppressed ACTH levels was previously unknown and was considered to be an 'autonomous' process. Recent work by several groups has demonstrated that cortisol secretion in most AIMAH and some adrenal adenomas is regulated by hormones other than ACTH via the ectopic expression or the overactive eutopic expression of several membrane-bound hormone receptors. Most of these receptors belong to the superfamily of $\mathrm{G}$ protein-coupled receptors that have become aberrantly coupled to steroidogenesis. This concept was first proposed by Schorr and Ney [59] who demonstrated in vitro that corticosterone production in adrenocortical carcinoma cells was stimulated by hormones other than $\mathrm{ACTH}$, such as catecholamines and TSH.

\section{GIP-Responsive AIMAH}

Food-dependent cortisol production was first identified in a patient with a cortisol-producing unilateral adenoma [60]. Two well-characterized in vivo examples of GIP-dependent hypercortisolism were described simultaneously by 2 independent groups in 1992 [61, 62]. It was observed in both patients with AIMAH and CS that cortisol production was stimulated by the postprandial physiological increase in plasma levels of GIP. Plasma cortisol levels were correlated with plasma GIP levels during various test meals. The presence of GIP receptors was further supported by adrenal imaging following the injection of [ $\left.{ }^{123} \mathrm{I}\right]-$ GIP [61]. GIP-dependent CS has now been described in over 17 patients with AIMAH [10, 25, 61-67] and in 7 patients with unilateral adenomas [10, 60, 68-71]. GIP-dependent oversecretion of both androgen and cortisol has been described in a patient with an adrenal adenoma presenting with hyperandrogenic symptoms [71]. The GIP receptor is ectopically expressed in the adrenal gland in these patients as it is normally not expressed in the normal fetal or adult adrenal cortex. It is expressed at the cell surface in a non-mutated form as assessed by sequence analysis of the full-length cDNA $[68,71,72]$. The expression of the GIP receptor can be detected in the early phases of adrenal hyperplasia [25]. In vitro, GIP increases cAMP production as well as DNA synthesis in GIP-dependent cortisol-secreting adenoma cells in primary culture, suggesting that GIP induces both hormonogenesis and cell proliferation [68]. The demonstration that bovine adrenal cells transfected with the GIP receptor and injected under the renal capsule in mice lead to the development of hyperplastic adrenals and hypercortisolism further supports the initiation role of the ectopic receptor in the pathophysiology of AIMAH [73].

\section{Vasopressin-Responsive CS}

Aberrant stimulation of cortisol secretion by vasopressin has been reported in adrenal CS independent of ACTH stimulation. A number of patients with both unilateral adenomas and AIMAH have been described in whom exogenous vasopressin or physiological stimuli of vasopressin secretion such as upright posture stimulate 
the secretion of cortisol $[15,74-77]$. In the majority of these cases, it was demonstrated that the action of vasopressin was mediated via non-mutated V1-vasopressin receptors that are expressed at similar or higher levels compared with controls [10, 15, 57, 74-83]. An exaggerated calcium flux and cortisol secretion were observed in vitro in adrenal cells incubated with vasopressin and these effects were inhibited by a V1-vasopressin receptor antagonist [79, 82, 84]. Given that the $\mathrm{V} 1$ receptor is normally expressed in the adrenal cortex and that its activation leads to a modest in vitro increase in steroidogenesis, the observed exaggerated steroidogenic response represents an aberrant response of a eutopic receptor. This may be the result of receptor overexpression and/or of a more efficient intracellular coupling to the steroidogenic pathways. The ectopic expression of V2- and V3-vasopressin receptors has been documented in vitro in adrenal tissue from patients with AIMAH; however, the in vivo demonstration of the effect of V2-vasopressin receptor in these cases is lacking $[15,76]$.

\section{Catecholamine-Responsive AIMAH}

In human adrenal glands, catecholamines have a direct modulatory effect on aldosterone, but not cortisol, secretion. The ectopic expression of $\beta$-adrenergic receptors was first reported in vitro in tissue from adrenal tumors associated with CS [10]. In vivo, aberrant responses to elevations in endogenous catecholamines as induced by upright posture, insulin-induced hypoglycemia and exercise were documented in 4 patients with AIMAH and CS [83, 85-87]. Furthermore, isoproterenol infusion stimulated cortisol and aldosterone secretion in these patients but failed to do so in normal subjects. These aberrant responses were reduced by pretreatment with propranolol, a $\beta$-adrenergic antagonist. Two cases have been reported in which combined aberrant responses of both $\beta$-adrenergic and V1-vasopressin receptors were demonstrated in vivo [83, 87]. High-affinity binding sites compatible with $\beta 1$ - and $\beta 2$-adrenergic receptors have been identified in the adrenal tissues of such patients and have been shown to be coupled functionally to steroidogenesis [86]. Further studies are needed to better characterize the subtype of adrenergic receptors present in these patients and to determine whether they are expressed in a nonmutated form.

\section{LH-Responsive AIMAH}

The $\mathrm{LH} / \mathrm{hCG}$ receptor is normally mainly expressed in the gonads [88]. In the human adrenal, this receptor has been identified by immunohistochemistry to be pres- ent only in the zona reticularis [89]. In the fetal adrenal gland, hCG stimulates DHEAS secretion [90]. The first description of an aberrant expression of the $\mathrm{LH} / \mathrm{hCG}$ receptor was that of a woman with AIMAH who had transient CS during pregnancy and persistent CS following menopause [91]. In this patient, cortisol secretion was stimulated by the exogenous administration of $\mathrm{GnRH}$, hCG, or recombinant LH. The administration of the long-acting GnRH agonist leuprolide acetate led to the suppression of endogenous LH production and to the subsequent normalization of cortisol secretion. The LH/hCG receptor was present in a non-mutated form and its expression was not increased compared with normal adrenal tissue [92]. In the same patient, plasma cortisol, free testosterone, and DHEAS were increased by oral intake of cisapride and metoclopramide, two serotonin 5-HT4 receptor agonists [75]. Another 2 patients were described with combined aberrant responses to LH/hCG receptor agonists and 5-HT4 agonists [93]. Bourdeau et al. [16] described 2 patients with subclinical CS who showed responses to both hCG and 5HT-4 in vivo. There has also been a report of a patient with combined aberrant responses to both hCG and GIP [94].

\section{Serotonin-Responsive AIMAH}

In the normal adrenal gland, 5-HT4 receptor agonists are potent stimulators of aldosterone secretion but only weakly affect cortisol secretion in vitro. In vivo, they normally do not produce an increase in plasma cortisol [95]. Cartier et al. [96] reported 6 cases of CS and AIMAH with aberrant responses to cisapride and demonstrated adrenal overexpression of the 5-HT4 receptor in the adrenal glands of 4 of these patients. Another group described a patient with cisapride-responsive CS and AIMAH in whom adrenal overexpression of the 5-HT4 receptor was also found [97]. A case of hyperaldosteronism and cyclical Cushing's with aberrant responses to both aldosterone and cortisol to 5-HT4 agonists has also been reported [20]. In addition to the eutopic overexpression of 5-HT4 receptors described above, ectopic expression of 5-HT7 receptors has been demonstrated in patients with AIMAH and CS [76].

\section{Angiotensin-Responsive AIMAH}

The possibility of adrenal hypersensitivity to angiotensin II was entertained in a patient with AIMAH and CS in whom a large increase in plasma aldosterone and cortisol were noted during upright posture [98]. The shortterm oral administration of candesartan, an AT-1 receptor antagonist, completely eliminated the stimulation of 


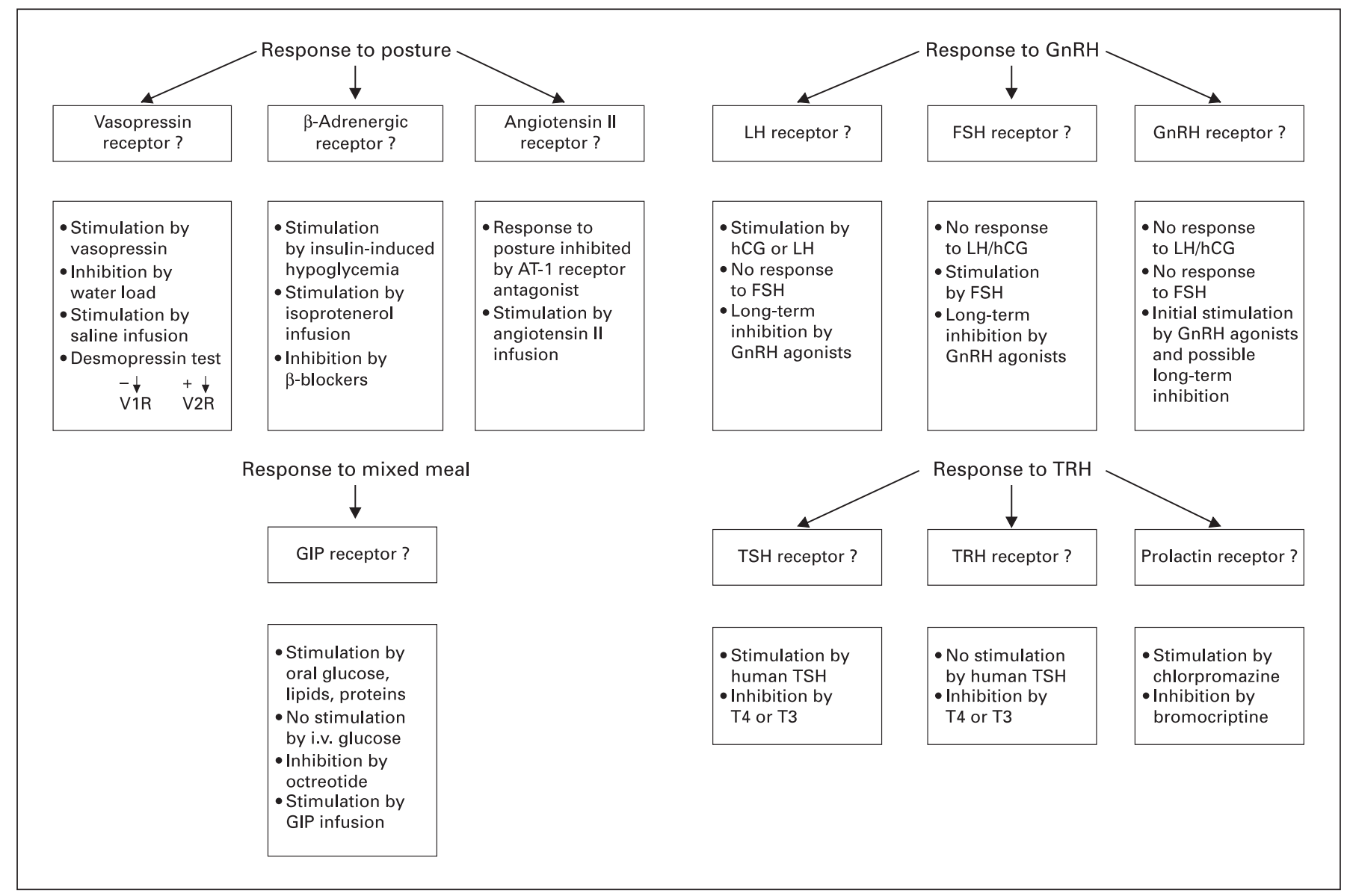

Fig. 2. Investigative protocol to further characterize abnormal adrenal hormone receptors following the initial screening protocol. Reproduced with permission from Lacroix et al. [108].

these adrenal hormones. An angiotensin infusion was not performed nor was a trial of long-term pharmacotherapy with an AT-1 receptor blocker attempted. In vitro stimulation of cortisol secretion in adrenal tissue by angiotensin II from patients with AIMAH has been shown but the presence of the AT-1 receptor has never been demonstrated [99].

\section{Other Abnormal Responses in AIMAH}

Leptin synthesis is stimulated by glucocorticoids and this hormone normally inhibits cortisol secretion in the adrenal gland [100-102]. In a patient with AIMAH and CS, GIP and leptin were shown to aberrantly increase cortisol production in vitro. The GIP and leptin receptors were not measured directly in this case [64]. These responses have never been demonstrated in vivo. Two patients with AIMAH and CS have been described in whom insulin-induced hypoglycemia stimulated cortisol production while ACTH levels remained undetectable [103, 104]. In vitro, adrenal cortisol secretion was not stimulated by insulin, catecholamines, vasopressin, or angiotensin II [104]. Other in vitro studies of adrenal material from both benign and malignant lesions have suggested the expression of other aberrant membrane receptors such as thyrotropin, FSH, and IL-1 [10, 105, 106].

A patient with AIMAH and CS was recently described in whom an increased adrenocortical expression of POMC/ACTH was described, thus suggesting a paracrine regulatory mechanism of hypercortisolism [107].

\section{Investigative Protocol for Aberrant Receptors}

An investigative protocol to screen patients with adrenal Cushing's for aberrant receptors has been developed and has been previously described in detail [108]. The 
strategy consists of modulating the plasma levels of various hormones (endogenous or exogenous) or pharmacologic receptor ligands while monitoring levels of plasma $\mathrm{ACTH}$, cortisol, and other steroid hormones.

All tests are performed following an overnight fast and in a supine position for at least $1 \mathrm{~h}$. The initial screening is performed over the course of 3 days and involves: (1) a posture test to screen for receptors to angiotensin II, vasopressin, catecholamines, or atrial natriuretic peptides; (2) ingestion of a standard mixed meal to assess the presence of GIP or other gastrointestinal hormone receptors; (3) administration of $\mathrm{GnRH}$ to screen for responses to GnRH, LH, and FSH; (4) administration of TRH to screen for modulation by TRH, TSH, or prolactin; (5) administration of glucagon; (6) administration of argininevasopressin, and (7) administration of cisapride or metoclopramide, serotonin 5-HT4 receptor agonists. Serial measurements of ACTH and cortisol are performed at 30to 60 -min intervals over the course of $2-3 \mathrm{~h}$ following the intervention. A change of $25-49 \%$ from the baseline cortisol levels in the absence of an increase in ACTH is defined as a partial response and a change of $50 \%$ or greater is considered a positive response to the specific ligand [10]. If a partial or positive cortisol response is elicited, the test is repeated to assess its reproducibility and to examine whether or not other steroids are simultaneously stimulated. Fluctuations of the ligand hormones of interest are also measured to better define the modulator of the response. If a positive response following this initial screening is clearly documented, further stimulatory tests are undertaken in order to precisely implicate a hormone or a more specific receptor type (fig. 2).

\section{Frequency of Aberrant Receptor Responses in}

\section{AIMAH}

Individual case reports fail to provide information on the frequency of aberrant receptors in AIMAH. In a systematic clinical screening of 20 consecutive patients with adrenal CS, all 6 patients with AIMAH had evidence of at least one aberrant receptor type: 2 GIP receptors; $1 \mathrm{~V} 1$ vasopressin receptor; $1 \mathrm{LH} / \mathrm{hCG}$ receptor and 5-HT4 receptor; $1 \beta$-adrenergic receptor, and $1 \beta$-adrenergic receptor and V1-vasopressin receptor [83]. In the same series, aberrant receptor responses were identified in only 3 of 13 patients with unilateral adenomas and none in one adrenal carcinoma. In a similar study by the French COMET multicenter group, 11 patients with AIMAH were systematically screened and were all found to have aberrant responses of cortisol secretion to at least one and often several stimuli [109]. In an in vitro screening study,
4 of 8 adrenals from AIMAH patients were found to express the GIP receptor in contrast to only 1 of 16 unilateral adenomas [66].

Two groups have reported the frequency of aberrant receptors in patients with AIMAH and subclinical CS. Four of 4 patients systematically screened with incidentally discovered AIMAH and biochemically confirmed subclinical CS were found to exhibit an aberrant receptor response: 2 combined V1-vasopressin receptor, $\mathrm{LH} / \mathrm{hCG}$ receptor and 5-HT4 receptor; 1 combined V1-vasopressin receptor and 5-HT4 receptor, and 1 with V1-vasopressin receptor only [16]. Tatsuno et al. [110] reported 5 patients with AIMAH and subclinical CS who all showed a positive in vivo response to AVP. Overexpression of V1-AVP receptor mRNA by RT-PCR was shown in the 1 patient who was studied in more detail. Other aberrant responses were not systematically screened [110].

These studies convincingly suggest that most patients with AIMAH and CS, when systematically screened, have an aberrant stimulation of cortisol suggesting the expression of an illicit receptor in their adrenal glands. Based on these data and on the potential therapeutic implications of identifying an aberrant response (see later), we recommend that all patients with AIMAH and CS undergo screening as outlined by the screening protocol described above. The data for patients with AIMAH and subclinical $\mathrm{CS}$ are more scant and the screening protocol should be performed in the context of research protocols.

\section{Molecular Mechanisms of Aberrant Receptors}

The molecular mechanisms by which eutopic receptors and non-mutated ectopic receptors are expressed in the adrenal glands of patients with AIMAH and less commonly in adrenal adenomas are largely unknown. One may hypothesize that these aberrant receptors represent a primary phenomenon that is essential to the pathogenesis of AIMAH (resulting in both the hyperplasia and the hypercortisolism). Alternatively, this aberrant receptor expression may be an epiphenomenon as a result of cell proliferation and dedifferentiation. A number of observations would favor the former hypothesis including the presence of aberrant receptors in all patients with AIMAH who were systematically screened [83, 109], the in vitro stimulation of both hormonogenesis and cell division by the different implicated ligands [68], and the reversal of hyperplasia between pregnancies in LH/hCG-dependent CS [25]. Following this primary phenomenon, other genetic events may accumulate over time, as suggested by microarray data [35], that lead to additional proliferation signals and the formation of monoclonal nodules. This 
mechanism is consistent with the finding of both monoclonal and polyclonal lesions within the same gland [78, 111-113].

The dysregulation of tissue-specific expression of membrane receptors implies either the disruption of cisacting regulatory elements (promoters) or trans-acting elements (transcription factors/co-activators/co-repressors). This disruption must occur at an early stage of embryogenesis as the pathology involves the entire adrenal cortex. No mutations or polymorphisms were encountered in the promoter region of the GIP-receptor gene in GIP-dependent CS [114]. The identification of trans-acting elements implicated in tissue-specific expression of the hGIP receptor and their potential alterations are currently under way [115]. Alteration of trans-acting elements may be more likely and more consistent with the common co-expression of several aberrant receptors.

Kero et al. [116] have provided another interesting hypothesis. They demonstrated that chronic stimulation with $\mathrm{LH}$ in transgenic mice leads to adrenal CS as a result of $\mathrm{LH} / \mathrm{hCG}$ receptor expression in the adrenal cortex. The expression of these ectopic receptors was thought to be the result of elevated estrogen levels as it was no longer observed following gonadectomy.

\section{Management of AIMAH}

Bilateral adrenalectomy is the treatment of choice in nearly all patients with AIMAH and CS. However, several case reports propose unilateral adrenalectomy as a safe and effective alternative [117]. A small series described 4 consecutive patients with AIMAH and CS in whom unilateral adrenalectomy was performed [118]. All patients experienced a clinical improvement and normalized their 24-hour urinary cortisol excretion but maintained an abnormal circadian rhythm and lack of suppression following dexamethasone administration. Their contralateral glands did not enlarge during 62-126 months of follow-up. However, the persistence of the subtle abnormalities of cortisol secretion in the subclinical CS range should cause concern as it has been shown to be associated with increased morbidity [119].

The identification of aberrant adrenal receptors provides the novel and interesting opportunity to treat selected patients with AIMAH and CS with pharmacologic agents. Octreotide administration was attempted in a few patients with GIP-dependent CS. The initial response to treatment was positive but long-term treatment proved to be ineffective $[62,67,69]$. In a patient with aberrant $\beta$-adrenergic receptors and AIMAH, propranolol decreased cortisol secretion to approximately 2 times the upper limit of normal and was able to completely normalize cortisol secretion following only unilateral adrenalectomy [86]. Long-acting GnRH agonist treatment with leuprolide acetate has been shown to normalize cortisol secretion in a patient with AIMAH and LH-dependent CS as well as in a patient with LH-dependent subclinical CS [16]. The absence of adrenal insufficiency was hypothesized to be the result of the concomitant stimulation via the 5-HT4 receptors. Goodarzi et al. [22] described a case of androgen-secreting AIMAH with an aberrant $\mathrm{LH} / \mathrm{hCG}$ response in whom leuprolide acetate normalized androgen secretion. In contrast to the above successful treatment with a GnRH agonist, leuprolide acetate provided only a partial and transient decrease in cortisol production in another woman with aberrant responses to GnRH, $\mathrm{LH}$, and hCG, suggesting the presence of unidentified aberrant receptors or post-receptor mechanisms [120]. A partial response to OPC-21268, a V1a-receptor antagonist, has been described in a patient with vasopressin-responsive CS [79]. These treatments have never been shown to reduce the size of the adrenal glands. The discovery of other aberrant receptors and the development of novel specific receptor antagonists will undoubtedly lead to a more widespread use of pharmacological manipulation for the treatment of AIMAH. It will also be of great interest to investigate whether treatment with these agents will alter the natural history of AIMAH when discovered in its subclinical stages.

The use of ketoconazole, an inhibitor of steroidogenesis, has been shown to be effective in restoring eucortisolism, especially in preparation for adrenalectomy [40, 121, 122]. The use of metyrapone and mitotane has also been reported in the literature in selected cases of AIMAH with CS [123].

In patients with subclinical CS, the decision to treat should be based on the age of the patient and the morbidity associated with the hypercortisolic state: hypertension, diabetes, osteoporosis, and neuropsychological manifestations. Follow-up with annual adrenal CT scan and biochemical assessment should be done in all these patients as the natural history of subclinical AIMAH is currently unknown. Taking into account recent reports of familial cases of AIMAH, it also appears justified to screen family members of patients with AIMAH for subclinical disease with overnight $1 \mathrm{mg}$ dexamethasone test, late-night salivary cortisol, and adrenal CT scan. 


\section{References}

1 Nieman LK: Cushing's syndrome; in De Groot LJ, Jameson JLe, Burger HG, et al (eds): Endocrinology, ed 4. Philadelphia, Saunders, 2000, pp 1691-1720.

-2 Lieberman SA, Eccleshall TR, Feldman D: ACTH-independent massive bilateral adrenal disease (AIMBAD): A subtype of Cushing's syndrome with major diagnostic and therapeutic implications. Eur J Endocrinol 1994;131: 67-73.

3 Stratakis CA, Kirschner LS: Clinical and genetic analysis of primary bilateral adrenal diseases (micro- and macronodular disease) leading to Cushing syndrome. Horm Metab Res 1998;30:456-463.

4 Swain JM, Grant CS, Schlinkert RT, Thompson GB, van Heerden JA, Lloyd RV, Young WF: Corticotropin-independent macronodular adrenal hyperplasia: A clinicopathologic correlation. Arch Surg 1998;133:541-545.

$\checkmark 5$ Kirschner MA, Powell RD Jr, Lipsett MB: Cushing's syndrome: Nodular cortical hyperplasia of adrenal glands with clinical and pathological features suggesting adrenocortical tumor. J Clin Endocrinol Metab 1964;24:947955.

6 Kirk JM, Brain CE, Carson DJ, Hyde JC, Grant DB: Cushing's syndrome caused by nodular adrenal hyperplasia in children with McCune-Albright syndrome. J Pediatr 1999;134: 789-792.

7 Malchoff CD, MacGillivray D, Malchoff DM: Adrenocorticotropic hormone-independent adrenal hyperplasia. Endocrinologist 1996;6: 79-85.

-8 Zeiger MA, Nieman LK, Cutler GB, Chrousos GP, Doppman JL, Travis WD, Norton JA: Primary bilateral adrenocortical causes of Cushing's syndrome. Surgery 1991;110:11061115 .

-9 Aiba M, Hirayama A, Iri H, Ito Y, Fujimoto Y, Mabuchi G, Murai M, Tazaki H, Maruyama $\mathrm{H}$, Saruta T: Adrenocorticotropic hormone-independent bilateral adrenocortical macronodular hyperplasia as a distinct subtype of Cushing's syndrome. Enzyme histochemical and ultrastructural study of four cases with a review of the literature. Am J Clin Pathol 1991;96: 334-340.

10 Lacroix A, N'Diaye N, Tremblay J, Hamet P: Ectopic and abnormal hormone receptors in adrenal Cushing's syndrome. Endocr Rev 2001;22:75-110.

-11 Minami S, Sugihara H, Sato J, Tatsukuchi A, Sugisaki Y, Sasano H, Wakabayashi I: ACTH independent Cushing's syndrome occurring in siblings. Clin Endocrinol (Oxf) 1996;44:483488.

-12 Nies C, Bartsch DK, Ehlenz K, Wild A, Langer $\mathrm{P}$, Fleischhacker S, Rothmund M: Familial ACTH-independent Cushing's syndrome with bilateral macronodular adrenal hyperplasia clinically affecting only female family members. Exp Clin Endocrinol Diabetes 2002;110: 277-283.
13 Findlay JC, Sheeler LR, Engeland WC, Aron DC: Familial adrenocorticotropin-independent Cushing's syndrome with bilateral macronodular adrenal hyperplasia. J Clin Endocrinol Metab 1993;76:189-191.

14 Imohl M, Koditz R, Stachon A, Muller KM, Nicolas V, Pfeilschifter J, Krieg M: Catecholamine-dependent hereditary Cushing's syndrome - Follow-up after unilateral adrenalectomy (in German). Med Klin (Munich) 2002; 97:747-753.

15 Lee S, Jun S, Hong SW, Kim DJ, Rhee Y, Lim SK: Familial adrenocorticotropin-independent macronodular adrenal hyperplasia: Ectopic expression of vasopressin V1b, V2 receptors in the adrenal gland (abstract). 86th Meeting of the Endocrine Society, New Orleans, 2004, p 566.

16 Bourdeau I, D’Amour P, Hamet P, Boutin JM, Lacroix A: Aberrant membrane hormone receptors in incidentally discovered bilateral macronodular adrenal hyperplasia with subclinical Cushing's syndrome. J Clin Endocrinol Metab 2001;86:5534-5540.

17 Ohashi A, Yamada Y, Sakaguchi K, Inoue T, Kubo M, Fushimi H: A natural history of adrenocorticotropin-independent bilateral adrenal macronodular hyperplasia (AIMAH) from preclinical to clinically overt Cushing's syndrome. Endocr J 2001;48:677-683.

18 Yamada Y, Sakaguchi K, Inoue T, Kubo M, Fushimi H, Sekii K, Itatani H, Tsujimura T, Kameyama M: Preclinical Cushing's syndrome due to adrenocorticotropin-independent bilateral adrenocortical macronodular hyperplasia with concurrent excess of gluco- and mineralocorticoids. Intern Med 1997;36:628632.

19 Hayashi Y, Takeda Y, Kaneko K, Koyama H, Aiba M, Ikeda U, Shimada K: A case of Cushing's syndrome due to ACTH-independent bilateral macronodular hyperplasia associated with excessive secretion of mineralocorticoids. Endocr J 1998;45:485-491.

20 Yared Z, Antonini S, Lacroix A: Macronodular adrenal hyperplasia with long-term primary hyperaldosteronism and recent cyclical Cushing's syndrome with aberrant response of cortisol to serotonin agonist 5-HT4 R (abstract). 85th Meeting of the Endocrine Society, Philadelphia, 2003, p 445.

-21 Malchoff CD, Rosa J, DeBold CR, Kozol RA, Ramsby GR, Page DL, Malchoff DM, Orth DN: Adrenocorticotropin-independent bilateral macronodular adrenal hyperplasia: An unusual cause of Cushing's syndrome. J Clin Endocrinol Metab 1989;68:855-860.

22 Goodarzi MO, Dawson DW, Li X, Lei Z, Shintaku P, Rao CV, Van Herle AJ: Virilization in bilateral macronodular adrenal hyperplasia controlled by luteinizing hormone. J Clin Endocrinol Metab 2003;88:73-77.
23 Doppman JL, Nieman LK, Travis WD, Miller DL, Cutler GB Jr, Chrousos GP, Norton JA: $\mathrm{CT}$ and MR imaging of massive macronodular adrenocortical disease: A rare cause of autonomous primary adrenal hypercortisolism. J Comput Assist Tomogr 1991;15:773-779.

24 Rockall AG, Babar SA, Sohaib SA, Isidori AM, Diaz-Cano S, Monson JP, Grossman AB, Reznek RH: CT and MR imaging of the adrenal glands in ACTH-independent Cushing syndrome. Radiographics 2004;24:435-452.

25 N'Diaye N, Hamet P, Tremblay J, Boutin JM, Gaboury L, Lacroix A: Asynchronous development of bilateral nodular adrenal hyperplasia in gastric inhibitory polypeptide-dependent Cushing's syndrome. J Clin Endocrinol Metab 1999;84:2616-2622.

26 Doppman JL, Chrousos GP, Papanicolaou DA, Stratakis CA, Alexander HR, Nieman LK: Adrenocorticotropin-independent macronodular adrenal hyperplasia: An uncommon cause of primary adrenal hypercortisolism. Radiology 2000;216:797-802.

27 Smals AG, Pieters GF, van Haelst UJ, Kloppenborg PW: Macronodular adrenocortical hyperplasia in long-standing Cushing's disease. J Clin Endocrinol Metab 1984;58:25-31.

28 Sasano H, Suzuki T, Nagura H: ACTH-independent macronodular adrenocortical hyperplasia: Immunohistochemical and in situ hybridization studies of steroidogenic enzymes. Mod Pathol 1994;7:215-219.

$\checkmark 29$ Aiba M, Kawakami M, Ito Y, Fujimoto Y, Suda T, Demura H: Bilateral adrenocortical adenomas causing Cushing's syndrome. Report of two cases with enzyme histochemical and ultrastructural studies and a review of the literature. Arch Pathol Lab Med 1992;116: 146-150.

30 Cugini P, Battisti P, Di Palma L, Sepe M, Kawasaki T, Uezono K, Sasaki H: 'GIANT' macronodular adrenal hyperplasia causing Cushing's syndrome: Case report and review of the literature on a clinical distinction of adrenocortical nodular pathology associated with hypercortisolism. Endocrinol Jpn 1989;36:101-116.

31 Koizumi S, Beniko M, Ikota A, Mizumoto H, Matsuya K, Matsuda A, Sakuma S, Mashio Y, Kunita H, Okamoto K: Adrenocorticotropic hormone-independent bilateral adrenocortical macronodular hyperplasia: A case report and immunohistochemical studies. Endocr J 1994; 41:429-435.

32 Wada N, Kubo M, Kijima H, Ishizuka T, Saeki T, Koike T, Sasano H: Adrenocorticotropinindependent bilateral macronodular adrenocortical hyperplasia: Immunohistochemical studies of steroidogenic enzymes and post-operative course in two men. Eur J Endocrinol 1996;134:583-587.

33 Morioka M, Ohashi Y, Watanabe H, Komatsu F, Jin TX, Suyama B, Tanaka H: ACTH-independent macronodular adrenocortical hyperplasia (AIMAH): Report of two cases and the analysis of steroidogenic activity in adrenal nodules. Endocr J 1997;44:65-72. 
-34 Sasano H: Localization of steroidogenic enzymes in adrenal cortex and its disorders. Endocr J 1994;41:471-482.

-35 Bourdeau I, Antonini S, Lacroix A, Kirschner LS, Lorang D, Libutti SK, Stratakis CA: Gene array analysis of macronodular adrenal hyperplasia confirms clinical heterogeneity and identifies several genes as molecular mediators. Oncogene 2004;26:1575-1585.

-36 Bourdeau I, D’Amour P, Hamet P, Boutin JM, Lacroix A: Aberrant membrane hormone receptors in incidentally discovered bilateral macronodular adrenal hyperplasia with subclinical Cushing's syndrome. J Clin Endocrinol Metab 2001;86:5534-5540.

\37 Doppman JL, Miller DL, Dwyer AJ, Loughlin T, Nieman L, Cutler GB, Chrousos GP, Oldfield E, Loriaux DL: Macronodular adrenal hyperplasia in Cushing disease. Radiology 1988; 166:347-352.

- 38 Hermus AR, Pieters GF, Smals AG, Pesman GJ, Lamberts SW, Benraad TJ, van Haelst UJ, Kloppenborg PW: Transition from pituitarydependent to adrenal-dependent Cushing's syndrome. N Engl J Med 1988;318:966-970.

-39 Sturrock ND, Morgan L, Jeffcoate WJ: Autonomous nodular hyperplasia of the adrenal cortex: Tertiary hypercortisolism? Clin Endocrinol (Oxf) 1995;43:753-758.

40 Hocher B, Bahr V, Dorfmuller S, Oelkers W: Hypercortisolism with non-pigmented micronodular adrenal hyperplasia: Transition from pituitary-dependent to adrenal-dependent Cushing's syndrome. Acta Endocrinol (Copenh) 1993;128:120-125.

41 Choi Y, Werk EE, Jr., Sholiton LJ: Cushing's syndrome with dual pituitary-adrenal control. Arch Intern Med 1970;125:1045-1049.

-42 Aron DC, Findling JW, Fitzgerald PA, Brooks RM, Fisher FE, Forsham PH, Tyrrell JB: Pituitary ACTH dependency of nodular adrenal hyperplasia in Cushing's syndrome. Report of two cases and review of the literature. Am J Med 1981;71:302-306.

-43 Cheitlin RA, Westphal M, Cabrera CM, Fujii DK, Snyder J, Fitzgerald PA: Cushing's syndrome due to bilateral adrenal macronodular hyperplasia with undetectable ACTH: Cell culture of adenoma cells on extracellular matrix. Horm Res 1988;29:162-167.

44 Light K, Jenkins PJ, Weber A, Perrett C, Grossman A, Pistorello M, Asa SL, Clayton RN, Clark AJ: Are activating mutations of the adrenocorticotropin receptor involved in adrenal cortical neoplasia? Life Sci 1995;56:1523-1527.

-45 Latronico AC, Reincke M, Mendonca BB, Arai K, Mora P, Allolio B, Wajchenberg BL, Chrousos GP, Tsigos C: No evidence for oncogenic mutations in the adrenocorticotropin receptor gene in human adrenocortical neoplasms. J Clin Endocrinol Metab 1995;80:875-877.

-46 Fragoso MC, Domenice S, Latronico AC, Martin RM, Pereira MA, Zerbini MC, Lucon AM, Mendonca BB: Cushing's syndrome secondary to adrenocorticotropin-independent macronodular adrenocortical hyperplasia due to activating mutations of GNAS1 gene. J Clin Endocrinol Metab 2003;88:2147-2151.
47 Swords FM, Baig A, Malchoff DM, Malchoff CD, Thorner MO, King PJ, Hunyady L, Clark AJ: Impaired desensitization of a mutant adrenocorticotropin receptor associated with apparent constitutive activity. Mol Endocrinol 2002; 16:2746-2753.

48 Swords FM, Noon LA, King PJ, Clark AJ: Constitutive activation of the human ACTH receptor resulting from a synergistic interaction between two naturally occurring missence mutations in the MC2R gene. Mol Cell Endocrinol 2004;213:149-154.

49 Aarskog D, Tveteraas E: McCune-Albright's syndrome following adrenalectomy for Cushing's syndrome in infancy. J Pediatr 1968;73: 89-96.

50 Benjamin DR, McRoberts JW: Polyostotic fibrous dysplasia associated with Cushing syndrome. Arch Pathol 1973;96:175-178.

51 Mauras N, Blizzard RM: The McCune-Albright syndrome. Acta Endocrinol Suppl (Copenh) 1986;279:207-217.

52 Shenker A, Laue L, Kosugi S, Merendino JJJ, Minegishi T, Cutler GBJ: A constitutively activating mutation of the luteinizing hormone receptor in familial male precocious puberty. Nature 1993;365:652-654.

53 MacMahon HE: Albright's syndrome - Thirty years later. (Polyostotic fibrous dysplasia). Pathol Annu 1971;6:81-146.

54 Danon M, Robboy SJ, Kim S, Scully R, Crawford JD: Cushing syndrome, sexual precocity, and polyostotic fibrous dysplasia (Albright syndrome) in infancy. J Pediatr 1975;87:917921.

55 Bourdeau I, Lacroix A: G-protein mutations (Gs $\alpha$ and $G 12 \alpha$ ) are infrequent in the adrenal tissues with Cushing's syndrome secondary to ACTH-independent bilateral macronodular adrenal hyperplasia (abstract). 84th Meeting of the Endocrine Society, 2002, p 244.

56 Skogseid B, Larsson C, Lindgren PG, Kvanta E, Rastad J, Theodorsson Wide L, Wilander E, Oberg K: Clinical and genetic features of adrenocortical lesions in multiple endocrine neoplasia type 1. J Clin Endocrinol Metab 1992; 75:76-81.

57 Yamakita N, Murai T, Ito Y, Miura K, Ikeda T, Miyamoto K, Onami S, Yoshida T: Adrenocorticotropin-independent macronodular adrenocortical hyperplasia associated with multiple colon adenomas/carcinomas which showed a point mutation in the APC gene. Intern Med 1997;36:536-542.

58 Marchesa P, Fazio VW, Church JM, McGannon E: Adrenal masses in patients with familial adenomatous polyposis. Dis Colon Rectum 1997;40:1023-1028.

59 Schorr I, Ney RL: Abnormal hormone responses of an adrenocortical cancer adenyl cyclase. J Clin Invest 1971;50:1295-1300.

60 Hamet P, Larochelle P, Franks DJ, Cartier P, Bolte E: Cushing syndrome with food-dependent periodic hormonogenesis. Clin Invest Med 1987;10:530-533.
61 Lacroix A, Bolte E, Tremblay J, Dupre J, Poitras P, Fournier H, Garon J, Garrel D, Bayard F, Taillefer R, Flanagan RJ, Hamet P: Gastric inhibitory polypeptide-dependent cortisol hypersecretion - A new cause of Cushing's syndrome. N Engl J Med 1992;327:974-980.

62 Reznik Y, Allali-Zerah V, Chayvialle JA, Leroyer R, Leymarie $\mathrm{P}$, Travert $\mathrm{G}$, Lebrethon MC, Budi I, Balliere AM, Mahoudeau J: Fooddependent Cushing's syndrome mediated by aberrant adrenal sensitivity to gastric inhibitory polypeptide. N Engl J Med 1992;327:981986.

63 Lebrethon MC, Avallet O, Reznik Y, Archambeaud F, Combes J, Usdin TB, Narboni G, Mahoudeau J, Saez JM: Food-dependent Cushing's syndrome: Characterization and functional role of gastric inhibitory polypeptide receptor in the adrenals of three patients. J Clin Endocrinol Metab 1998;83:45144519.

64 Pralong FP, Gomez F, Guillou L, Mosimann F, Franscella S, Gaillard RC: Food-dependent Cushing's syndrome: Possible involvement of leptin in cortisol hypersecretion. J Clin Endocrinol Metab 1999;84:3817-3822.

65 Gerl H, Rohde W, Biering H, Schulz N, Lochs $\mathrm{H}$ : Food-dependent Cushing syndrome of long standing with mild clinical features (in German). Dtsch Med Wochenschr 2000;125: 1565-1568.

66 Groussin L, Perlemoine K, Contesse V, Lefebvre $\mathrm{H}$, Tabarin A, Thieblot $\mathrm{P}$, Schlienger JL, Luton JP, Bertagna X, Bertherat J: The ectopic expression of the gastric inhibitory polypeptide receptor is frequent in adrenocorticotropin-independent bilateral macronodular adrenal hyperplasia, but rare in unilateral tumors. J Clin Endocrinol Metab 2002;87:1980-1985.

67 Croughs RJ, Zelissen PM, Van Vroonhoven ThJ, Hofland LJ, N'Diaye N, Lacroix A, de Herder WW: GIP-dependent adrenal Cushing's syndrome with incomplete suppression of ACTH. Clin Endocrinol (Oxf) 2000;52:235240.

68 Chabre O, Liakos P, Vivier J, Chaffanjon P, Labat-Moleur F, Martinie M, Bottari SP, Bachelot I, Chambaz EM, Defaye G, Feige JJ: Cushing's syndrome due to a gastric inhibitory polypeptide-dependent adrenal adenoma: Insights into hormonal control of adrenocortical tumorigenesis. J Clin Endocrinol Metab 1998; 83:3134-3143.

69 de Herder WW, Hofland LJ, Usdin TB, de Jong FH, Uitterlinden P, van Koetsveld P, Mezey E, Bonner TI, Bonjer HJ, Lamberts SW: Food-dependent Cushing's syndrome resulting from abundant expression of gastric inhibitory polypeptide receptors in adrenal adenoma cells. J Clin Endocrinol Metab 1996;81:31683172 .

70 Luton JP, Bertagna X: Membrane receptors and endocrine tumors: Expression of vasopressin receptor V1 modulates the pharmacologic phenotype of adrenocortical tumors (in French). Bull Acad Natl Med 1998;182:299_ 309 . 
71 Tsagarakis S, Tsigos C, Vassiliou V, Tsiotra P, Pratsinis H, Kletsas D, Trivizas P, Nikou A, Mavromatis T, Sotsiou F, Raptis S, Thalassinos N: Food-dependent androgen and cortisol secretion by a gastric inhibitory polypeptidereceptor expressive adrenocortical adenoma leading to hirsutism and subclinical Cushing's syndrome: In vivo and in vitro studies. J Clin Endocrinol Metab 2001;86:583-589.

72 N'Diaye N, Tremblay J, Hamet P, de Herder WW, Lacroix A: Adrenocortical overexpression of gastric inhibitory polypeptide receptor underlies food-dependent Cushing's syndrome. J Clin Endocrinol Metab 1998;83: 2781-2785.

73 Longo-Mazzuco T, Chabre O, Feige JJ, Thomas M: Démonstration du potentiel transformant du gène du récepteur du GIP dans les cellules du cortex surrénalien: un pas vers l'étiologie du syndrome de Cushing lié à l'alimentation. Ann Endocrinol (Paris) 2004; 65:267.

-74 Arnaldi G, Gasc JM, de Keyzer Y, Raffin-Sanson ML, Perraudin V, Kuhn JM, Raux-Demay MC, Luton JP, Clauser E, Bertagna X: Variable expression of the V1 vasopressin receptor modulates the phenotypic response of steroidsecreting adrenocortical tumors. J Clin Endocrinol Metab 1998;83:2029-2035.

75 Campbell KK, Baysdorfer C, Antonini S, Lacroix $A$ : V1 vasopressin receptor sequence and expression in adrenal Cushing's syndrome with aberrant response to vasopressin (abstract). 86th Meeting of the Endocrine Society, New Orleans, 2004, p 566.

76 Louiset E, Contesse V, Cartier D, Bertherat J, Duparc C, Barrande G, Groussin L, Vaudry H, Lefebvre H: Pharmacological profile and coupling mechanisms of illegitimate receptors in ACTH-independent macronodular bilateral adrenal hyperplasia causing Cushing's syndrome (abstract). 86th Meeting of the Endocrine Society, New Orleans, 2004, p 564.

$\checkmark 77$ Mune T, Murase H, Yamakita N, Fukuda T, Murayama M, Miura A, Suwa T, Hanafusa J, Daido H, Morita H, Yasuda K: Eutopic overexpression of vasopressin V1a receptor in adrenocorticotropin-independent macronodular adrenal hyperplasia. J Clin Endocrinol Metab 2002;87:5706-5713.

78 Beuschlein F, Reincke M, Karl M, Travis WD, Jaursch-Hancke C, Abdelhamid S, Chrousos GP, Allolio B: Clonal composition of human adrenocortical neoplasms. Cancer Res 1994; 54:4927-4932.

-79 Daidoh H, Morita H, Hanafusa J, Mune T, Murase H, Sato M, Shibata T, Suwa T, Ishizuka T, Yasuda K: In vivo and in vitro effects of AVP and V1a receptor antagonist on Cushing's syndrome due to ACTH-independent bilateral macronodular adrenocortical hyperplasia. Clin Endocrinol (Oxf) 1998;49:403-409.

$>80$ Horiba N, Suda T, Aiba M, Naruse M, Nomura K, Imamura M, Demura H: Lysine vasopressin stimulation of cortisol secretion in patients with adrenocorticotropin-independent macronodular adrenal hyperplasia. J Clin Endocrinol Metab 1995;80:2336-2341.
1 Iida K, Kaji H, Matsumoto H, Okimura Y, Abe H, Fujisawa M, Kamidono S, Chihara K: Adrenocorticotrophin-independent macronodular adrenal hyperplasia in a patient with lysine vasopressin responsiveness but insensitivity to gastric inhibitory polypeptide. Clin Endocrinol (Oxf) 1997;47:739-745.

82 Lacroix A, Tremblay J, Touyz RM, Deng LY, Lariviere R, Cusson JR, Schiffrin EL, Hamet $\mathrm{P}$ : Abnormal adrenal and vascular responses to vasopressin mediated by a V1-vasopressin receptor in a patient with adrenocorticotropinindependent macronodular adrenal hyperplasia, Cushing's syndrome, and orthostatic hypotension. J Clin Endocrinol Metab 1997; 82:2414-2422.

83 Mircescu H, Jilwan J, N'Diaye N, Bourdeau I, Tremblay J, Hamet P, Lacroix A: Are ectopic or abnormal membrane hormone receptors frequently present in adrenal Cushing's syndrome? J Clin Endocrinol Metab 2000;85: 3531-3536.

84 Perraudin V, Delarue C, de Keyzer Y, Bertagna X, Kuhn JM, Contesse V, Clauser E, Vaudry $\mathrm{H}$ : Vasopressin-responsive adrenocortical tumor in a mild Cushing's syndrome: In vivo and in vitro studies. J Clin Endocrinol Metab 1995; 80:2661-2667.

85 Pignatelli D, Rodrigues E, Barbosa AM, Medina JL: Cushing syndrome due to the ectopic expression of adrenergic receptors in the adrenal cortex. A case of ACTH independent macronodular adrenal hyperplasia (AIMAH) (abstract). 86th Meeting of the Endocrine Society, New Orleans, 2004, p 611.

86 Lacroix A, Tremblay J, Rousseau G, Bouvier M, Hamet P: Propranolol therapy for ectopic beta-adrenergic receptors in adrenal Cushing's syndrome. N Engl J Med 1997;337:1429_ 1434.

87 Miyamura N, Tsutsumi A, Senokuchi H, Nakamaru K, Kawashima J, Sakai K, Taguchi T, Tokunaga H, Nishida K, Uehara M, Sakakida M, Araki E: A case of ACTH-independent macronodular adrenal hyperplasia: Simultaneous expression of several aberrant hormone receptors in the adrenal gland. Endocr J 2003;50: 333-340.

88 Segaloff DL, Ascoli M: The lutropin/choriogonadotropin receptor. 4 years later. Endocr Rev 1993; 14:324-347.

89 Pabon JE, Li X, Lei ZM, Sanfilippo JS, Yussman MA, Rao CV: Novel presence of luteinizing hormone/chorionic gonadotropin receptors in human adrenal glands. J Clin Endocrinol Metab 1996;81:2397-2400.

90 Seron-Ferre M, Lawrence CC, Jaffe RB: Role of hCG in regulation of the fetal zone of the human fetal adrenal gland. J Clin Endocrinol Metab 1978;46:834-837.

91 Lacroix A, Hamet P, Boutin JM: Leuprolide acetate therapy in luteinizing hormone-dependent Cushing's syndrome. N Engl J Med 1999; 341:1577-1581.
92 N'Diaye N, Cartier D, Bourdeau I, Tremblay J, Hamet P, Lefebvre H, Lacroix A: Characterization of aberrant $\mathrm{LH} / \mathrm{hCG}$ and serotonin 5-HT4 receptors in adrenal Cushing's syndrome (abstract). 83rd Annual Meeting of the Endocrine Society, Denver, 2001, p 235.

$\checkmark 93$ Feelders RA, Lamberts SW, Hofland LJ, van Koetsveld PM, Verhoef-Post M, Themmen AP, de Jong FH, Bonjer HJ, Clark AJ, van der Lely AJ, de Herder WW: Luteinizing hormone (LH)-responsive Cushing's syndrome: The demonstration of $\mathrm{LH}$ receptor messenger ribonucleic acid in hyperplastic adrenal cells, which respond to chorionic gonadotropin and serotonin agonists in vitro. J Clin Endocrinol Metab 2003;88:230-237.

94 Bertherat J, Barrande G, Lefebvre H, RaffinSanson ML, Bertagna X: Systematic screening confirms that illicit membrane receptors are frequent and often multiple in bilateral ACTH-independent macronodular adrenal hyperplasia (AIMAH) (abstract). 83rd Annual Meeting of the Endocrine Society, Denver, 2001, p 233.

$\$ 95$ Lefebvre H, Contesse V, Delarue C, Vaudry H, Kuhn JM: Serotonergic regulation of adrenocortical function. Horm Metab Res 1998; 30:398-403.

96 Cartier D, Lihrmann I, Parmentier F, Bastard C, Bertherat J, Caron P, Kuhn JM, Lacroix A, Tabarin A, Young J, Vaudry H, Lefebvre $\mathrm{H}$ : Overexpression of serotonin4 receptors in cisapride-responsive adrenocorticotropin-independent bilateral macronodular adrenal hyperplasia causing Cushing's syndrome. J Clin Endocrinol Metab 2003;88:248-254.

97 Mannelli M, Ferruzzi P, Luciani P, Crescioli C, Buci L, Corona G, Serio M, Peri A: Cushing's syndrome in a patient with bilateral macronodular adrenal hyperplasia responding to cisapride: An in vivo and in vitro study. J Clin Endocrinol Metab 2003;88:46164622.

98 Nakamura Y, Son Y, Kohno Y, Shimono D, Kuwamura N, Koshiyama H, Sasano H, Matsuda T: Case of adrenocorticotropic hormone-independent macronodular adrenal hyperplasia with possible adrenal hypersensitivity to angiotensin II. Endocrine 2001;15: 57-61.

99 Bertherat J, Contesse V, Louiset E, Barrande G, Duparc C, Groussin L, Emy P, Bertagna X, Kuhn JM, Vaudry H, Lefebvre H: Abnormal sensitivity of the adrenocortical tissue to multiple stimuli in ACTH-independent macronodular adrenal hyperplasia (AIMAH) causing Cushing's syndrome: In vivo and in vitro studies (abstract). 86th Meeting of the Endocrine Society, New Orleans, 2004, p 562.

100 Slieker LJ, Sloop KW, Surface PL, Kriauciunas A, LaQuier F, Manetta J, Bue-Valleskey J, Stephens TW: Regulation of expression of ob mRNA and protein by glucocorticoids and cAMP. J Biol Chem 1996;271:5301-5304. 
101 Glasow A, Bornstein SR, Chrousos GP, Brown JW, Scherbaum WA: Detection of Obreceptor in human adrenal neoplasms and effect of leptin on adrenal cell proliferation. Horm Metab Res 1999;31:247-251.

- 102 Pralong FP, Roduit R, Waeber G, Castillo E, Mosimann F, Thorens B, Gaillard RC: Leptin inhibits directly glucocorticoid secretion by normal human and rat adrenal gland. Endocrinology 1998;139:4264-4268.

103 Makino S, Hashimoto K, Sugiyama M, Hirasawa R, Takao T, Ota Z, Saegusa M, Ohashi T, Omori H: Cushing's syndrome due to huge nodular adrenocortical hyperplasia with fluctuation of urinary 17-OHCS excretion. Endocrinol Jpn 1989;36:655-663.

104 Hashimoto K, Kawada Y, Murakami K, Hattori T, Suemaru S, Kageyama J, Ota Z, Hayata S, Ohashi T, Omori H: Cortisol responsiveness to insulin-induced hypoglycemia in Cushing's syndrome with huge nodular adrenocortical hyperplasia. Endocrinol Jpn 1986; 33:479-487.

105 Lacroix A, Baldacchino V, Bourdeau I, Hamet P, Tremblay J: Cushing's syndrome variants secondary to aberrant hormone receptors. Trends Endocrinol Metab 2004; 15 : 375-382.

106 Willenberg HS, Stratakis CA, Marx C, Ehrhart-Bornstein M, Chrousos GP, Bornstein SR: Aberrant interleukin-1 receptors in a cortisol-secreting adrenal adenoma causing Cushing's syndrome. N Engl J Med 1998;339: 27-31.

-107 Lefebvre H, Duparc C, Chartrel N, Jegou S, Pellerin A, Laquerriere A, Ivell R, Vaudry H, Kuhn JM: Intraadrenal adrenocorticotropin production in a case of bilateral macronodular adrenal hyperplasia causing Cushing's syndrome. J Clin Endocrinol Metab 2003;88: 3035-3042.

108 Lacroix A, Mircescu H, Hamet P: Clinical evaluation of the presence of abnormal hormone receptors in adrenal Cushing's syndrome. Endocrinologist 1999;9:9-15.
109 Bertherat J, Barrande G, Lefebvre H, et al: Illegitimate membrane receptors are frequent and often multiple in bilateral ACTH-independent macronodular adrenal hyperplasia (abstract). 85th Meeting of the Endocrine Society, Philadelphia, 2003, p 570.

110 Tatsuno I, Uchida D, Tanaka T, Koide H, Shigeta A, Ichikawa T, Sasano H, Saito Y: Vasopressin responsiveness of subclinical Cushing's syndrome due to ACTH-independent macronodular adrenocortical hyperplasia. Clin Endocrinol (Oxf) 2004;60:192200.

111 Gicquel C, Leblond-Francillard M, Bertagna X, Louvel A, Chapuis Y, Luton JP, Girard F, Le Bouc Y: Clonal analysis of human adrenocortical carcinomas and secreting adenomas. Clin Endocrinol (Oxf) 1994;40:465-477.

112 Gicquel C, Bertagna X, Le Bouc Y: Recent advances in the pathogenesis of adrenocortical tumours. Eur J Endocrinol 1995; 133:133144.

113 Diaz-Cano SJ, de Miguel M, Blanes A, Tashjian R, Galera H, Wolfe HJ: Clonality as expression of distinctive cell kinetics patterns in nodular hyperplasias and adenomas of the adrenal cortex. Am J Pathol 2000;156:311319.

114 Antonini SR, N'Diaye N, Baldacchino V, Hamet P, Tremblay J, Lacroix A: Analysis of the putative regulatory region of the gastric inhibitory polypeptide receptor gene in fooddependent Cushing's syndrome. J Steroid Biochem Mol Biol 2004;91:171-177.

115 Baldacchino V, Oble S, Hamet P, Tremblay J, Lacroix A: Partial characterisation of the 5' flanking region of the human GIP receptor (GIPR) gene. Endocr Res 2002;28:577.
116 Kero J, Poutanen M, Zhang FP, Rahman N, McNicol AM, Nilson JH, Keri RA, Huhtaniemi IT: Elevated luteinizing hormone induces expression of its receptor and promotes steroidogenesis in the adrenal cortex. J Clin Invest 2000;105:633-641.

117 Ogura M, Kusaka I, Nagasaka S, Yatagai T, Shinozaki S, Itabashi N, Nakamura T, Yokoyama M, Ishikawa SE, Ishibashi S: Unilateral adrenalectomy improves insulin resistance and diabetes mellitus in a patient with ACTH-independent macronodular adrenal hyperplasia. Endocr J 2003;50:715-721.

118 Lamas C, Alfaro JJ, Lucas T, Lecumberri B, Barcelo B, Estrada J: Is unilateral adrenalectomy an alternative treatment for ACTH- independent macronodular adrenal hyperplasia? Long-term follow-up of four cases. Eur J Endocrinol 2002;146:237-240.

119 Reincke M: Subclinical Cushing's syndrome. Endocrinol Metab Clin North Am 2000;29: 43-56.

120 Yared Z, Bourdeau I, Lacroix A: Failure to control Cushing's syndrome with leuprolide acetate in a case of ACTH-independent bilateral macronodular adrenal hyperplasia with partial regulation of cortisol secretion by $\mathrm{LH}$ and hCG (abstract). 84th Meeting of the Endocrine Society, San Francisco, 2002, p 649.

121 Arteaga E, Mahana D, Gonzalez R, Martinez P: Cushing syndrome caused by macronodular adrenal hyperplasia, independent of ACTH: Report of a case (in Spanish). Rev Med Chil 1989;117:1398-1402.

122 Lopez JM, Sapunar J, Donoso J, Martinez P: Cushing's syndrome due to bilateral adrenal macronodular hyperplasia. From ACTH-dependent hypercortisolism to ACTH-independent hypercortisolism (in Spanish). Rev Med Chil 1991;119:1165-1170.

123 Nagai M, Narita I, Omori K, Komura S, Arakawa M: Adrenocorticotropic hormone-independent bilateral adrenocortical macronodular hyperplasia treated with mitotane. Intern Med 1999;38:969-973. 